\title{
海水の剪断強度及び付着力に関する研究
}

A Study on the Shearing Strength and Adhesive Strength of Sea Ice

松下久雄*1 - 高脇 透*2 - 竹内貴弘*3 - 酒井雅史*4 - 寺島貴志*5 ・

Hisao Matsushita, Toru Takawaki, Takahiro Takeuchi, Masafumi Sakai, Takashi Terashima, 本田秀樹*6 - 正木孝治*6 - 西畑昭史 ${ }^{* 6}$ - 花田真州*6 - 佐伯 浩*7

Hideki Honda, Takaharu Masaki, Akifumi Nishihata, Masakuni Hanada, Hiroshi Saeki

In constructing an offshore structure in a sea area covered with ice it is necessary to understanding the ice load exerted by drift ice. To determine the adhesive and the shearing strengths, and their relation to the bending strength, we used the first-year ice of Notoro lagoon. To define the stress distribution of shear strength of the test specimen, we employed FEM elastic stress analysis. The adhesive strength test specimen kept outdoors separated at the attached surfaces, yielding an adhesive strength of $50 \mathrm{kPa}$. The shearing strength test specimen ruptured in bending. The shearing strength was found $0.2 \cdot 0.3 \mathrm{MPa}$.

Keywords : sea ice, shearing strength, adhesive strength, FEM analysis

1.はじめに

水海構造物にかかる水力を正確に求めるためには、海水の種々の強度特性を明らかにしておく必要がある。今

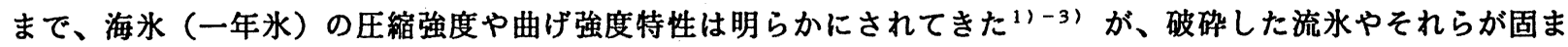
り水丘となった場合の海水強度に大きな影響を与える海水同士の付着力や剪断強度に関する研究は少ないように

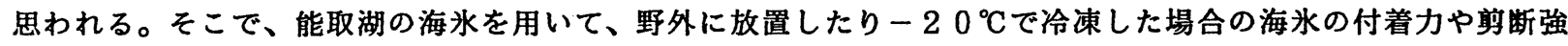
度を約 1 ケ月の経時変化で調べた。また、F E M 弾性応力解析を行い試験片の応力分布を明らかにし、破壊発生 部での強度を詳細に検討した。これらの結果から、付着力の経時変化、付着力や剪断強度と曲げ強度との関係等 を考察した。以上から氷力算定のための海水強度特性に関する基礎テー夕を得た。

2. 試験

2. 1 試験方法

試殹に用いた海水は能取湖の天然水 (一年水) で二見が丘漁港の岸壁から 沖合約 $15 \mathrm{~m}$ 離れた位置から採取した ものの中央部分（水平方向）である。

試医片は、図1 に示す形状寸法の付 着力試験片（A 試殹片）、剪断強度試 験片（S 試験片、S N 試験片（切欠を 付けたもの)）及び曲げ試験片 $B($ (三点 曲げ、幅 $45 X$ 厚 $45 X$ 支持点間 $200 \mathrm{~mm}$ ) と圧縮試験片c(直径 $75 X$ 長さ $150 \mathrm{~mm}$ ) である。各試験片の負荷方向は同一と した。ここで、A 試験片は、海水のブ

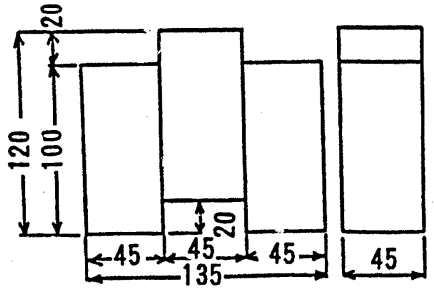

A 試験片

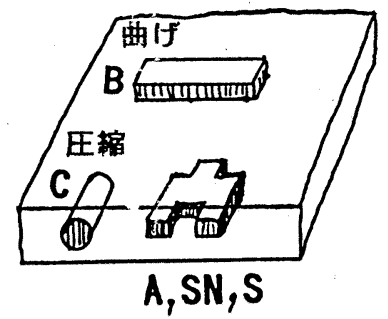

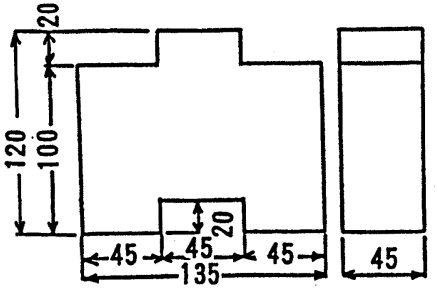

S 試験片

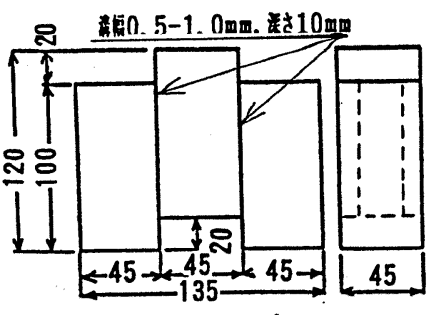

SN 試験片

図 1 試検片形状・寸法

*1 正会員 三井造船株式会社 船舶艦艇事業本部技術開発部（29.0 市原市八幡海岸通り 1 番地）

*2 株式会社三造試験センター *3 正会員 清水建設株式会社

*4 正会員 大成建設株式会社 *5 正会員 パシフィックコンサルタンツ株式会社

*6 学生会員 北海道大学大学院工学研究科土木工学専攻（研究当時）

*7 正会員 北海道大学工学部土木工学科 
ロック（幅45X厚さ $45 \mathrm{X}$ 長さ100mm） 3 つ重ね、海水に浸した雪 で付着させて製作した（図 2 参照）。S試唋片は、海办から淔接 切り出し、また、S N試験片は、S 試験片に鋸で溝幅 $0.5 \sim 1.0$ $\mathrm{mm}$, 深さ $10 \mathrm{~mm}$ の切欠きを試唋片両面に加工したものである。

$\mathrm{A}$ 試験片については、そのまま日の当たらない位置（図 3 参照） に9 日間及び 16 日間放置したもの、さらにそれぞれ 9、16日 間野外に放置後冷凍庫 $\left(-20{ }^{\circ} \mathrm{C}\right)$ 内に 9 日間保管したもの、及び 製作後すぐに冷凍庫に保管したものを用意した。S，S N 試质片 及び結晶組織観察用サンプルは、製作後すぐに冷東庫に保管した。

試鍳は、モーター駆動の一軸圧縮試験機を用い、歪み速度 $10^{-3}$ で行った。図 4 に試験状況を示す。

\section{2 換算式}

付着力及び章断強度は、（1）式を用いて計算した。

$\tau=\mathrm{P} / 2 \mathrm{~A}$

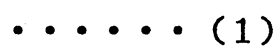

ここで、Pは荷重、A は付着部断面積（S N 試験片

では切欠部分の実断面積）

\section{3 試絤結果}

図 5 に野外放置した場合の付着力を示す。 この図から以下のことが分かる。尚、破壊 はすべて付着部分の剥れ破壊であった。

(1) 付着力は野外放置日数（9日間、 16 日間) にかかわらず、数十 $\mathrm{kPa}$ (水温 $-3^{\circ} \mathrm{C}$ ) である。

（2）野外放置後 9 日間冷凍すると、 ばらつきはあるが付着力は $0.1 \mathrm{MPa}$ 程度（水温 $-3^{\circ} \mathrm{C}$ ) になる。

因 6 に製作後すぐに冷凍した場合の剪断 強度や曲げ強度の経時変化を、図 7 に各試 験片の破壊経路を継めたものを、図 8 に冷 凍 10 日後の付着部の結晶構造写真を、 それぞれ示す。 これらから、以下のことが分かる。 （1）A 試験片の場合、 10 日間以上冷凍する と付着部は強固になり、 破壊は付着した部分に 限らず、S 試㕉片の場 合之同様、試験片下部 (凹部) から発生し（ 因 7 参照)、S 試検片 と同様の前断強度を示 す（図6参照）。 㰾断強度は0.2-0.3 $\mathrm{MPa}$ （水温 $-20^{\circ} \mathrm{C}$ 付近）。

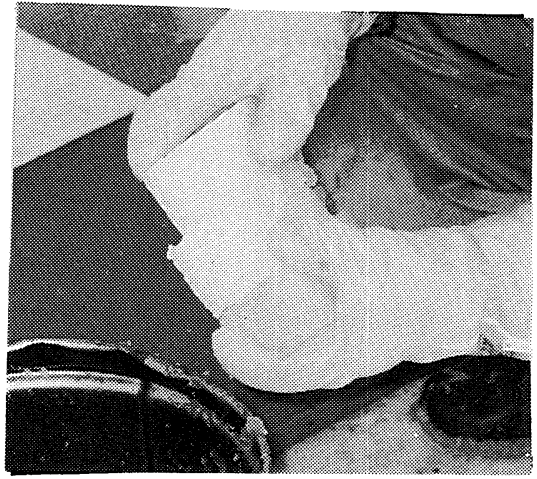

図 2 付着力試験片製作状况

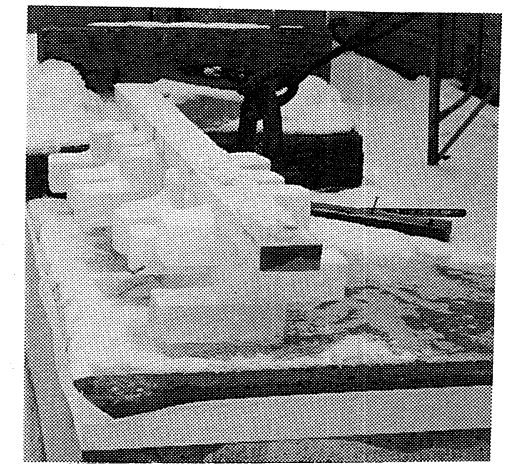

図 3 付着力試験片の野外放置状況

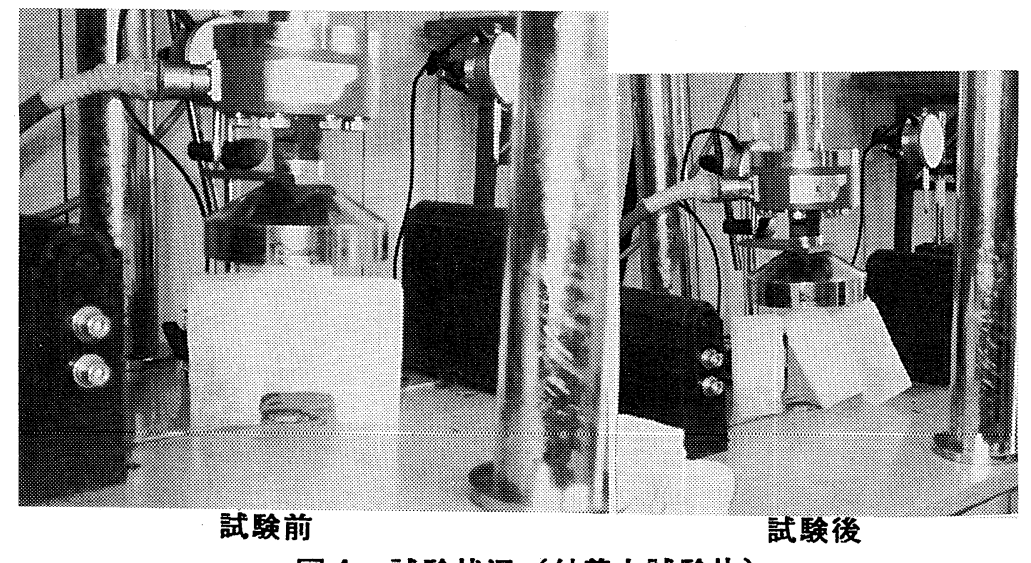

図4 試験状況（付着力試験片）

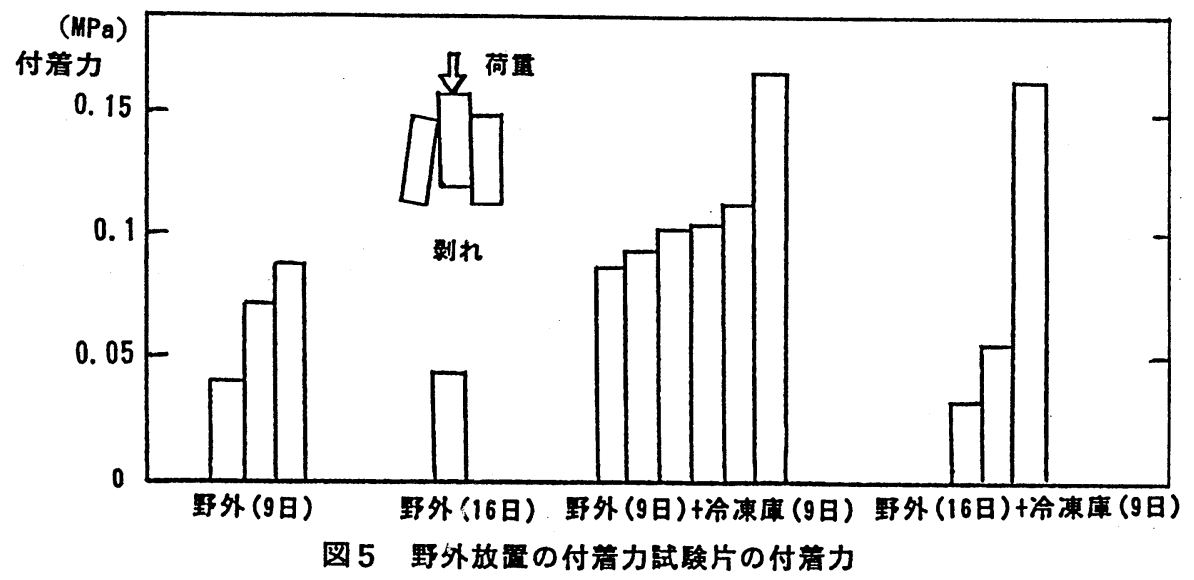


（2）各試殹片の強度 は、冷凍期間（10 29 日間）にかかわら ずほぼ一定である。曲 げ強度は、0.5 $\mathrm{MPa}$ (水 温 $\left.-20{ }^{\circ} \mathrm{C}\right)$ 前後で $-2{ }^{\circ} \mathrm{C}$ の値 $(0.28 \mathrm{IPa})$ の約 2 倍。尚、王樎強度は、 2. $5 \mathrm{PPa}$ (水温 $-20{ }^{\circ} \mathrm{C}$ ) 前後で $-0.3^{\circ} \mathrm{C}$ の値 $(0.4$ $\mathrm{MPa})$ の約 6 倍。

（3） S N試殹片の場 合には、試検片下部

(凹部) コーナーの切 欠端部が破壊発生位置 である。

(4) 剪断強度は曲げ 強度よりも小さい。 また、切欠を付けた場 合、ない場合に比べ、 剪断強度は若干大きく なる。

表 1 に実験結果を綨 めて示す。

尚、（3）、（4） については、後述する ように、今回の試釦片 形状による影響が大き いことからさらに検討 する必要があるものと 考える。

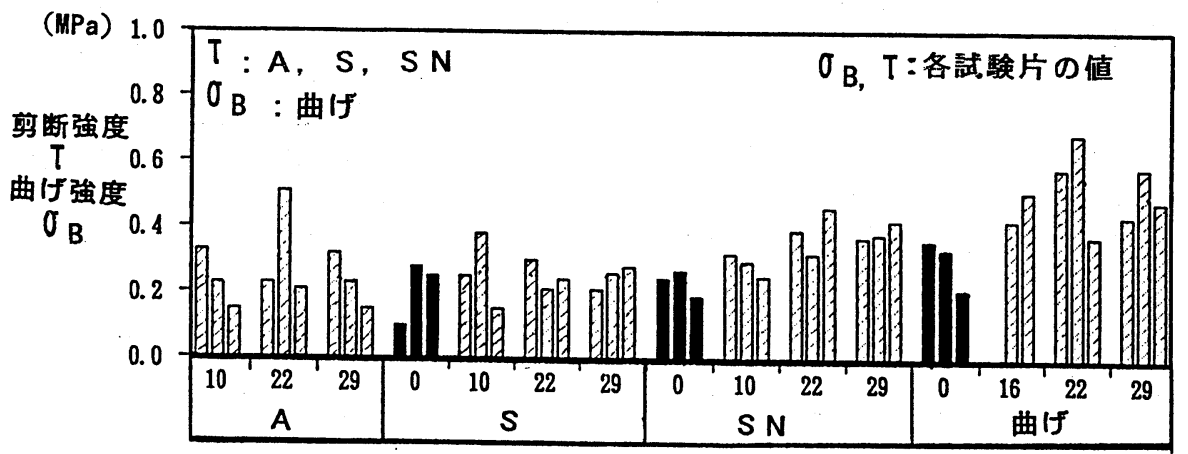

経過日数（日）

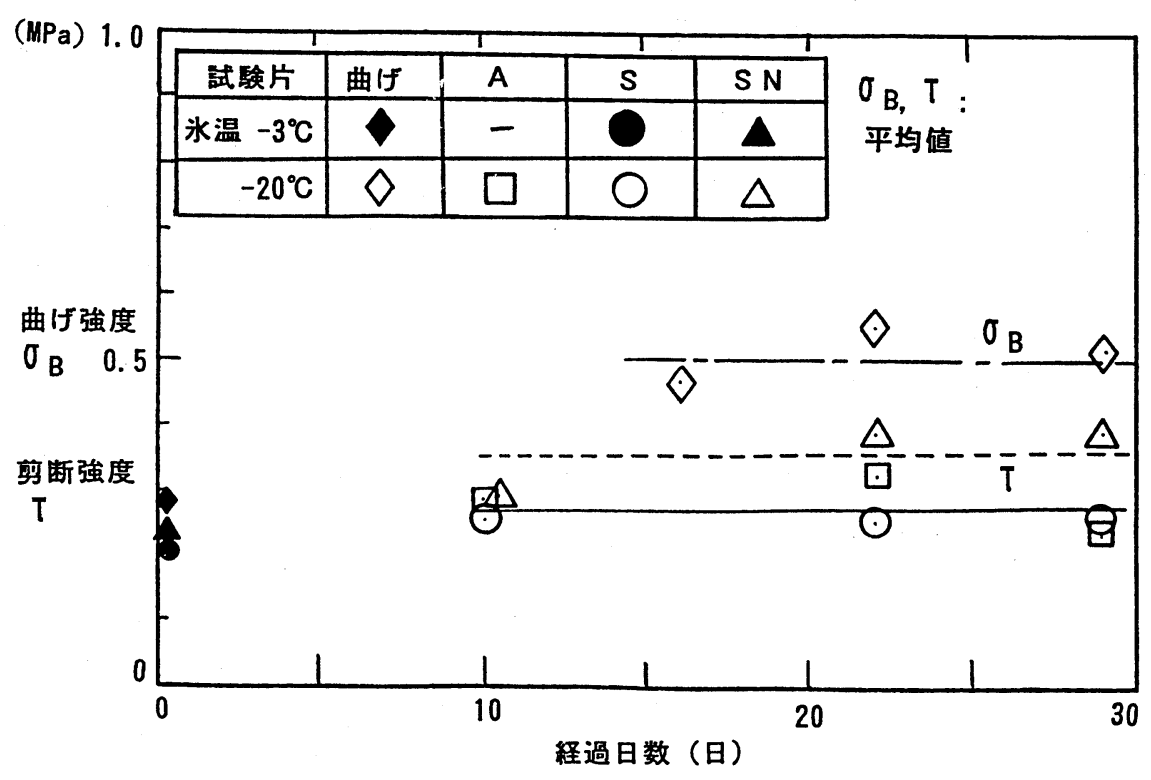

図6 製作後すぐに冷凍した場合の各式験片強度の経時変化

経過日数 0 日

試験片

A

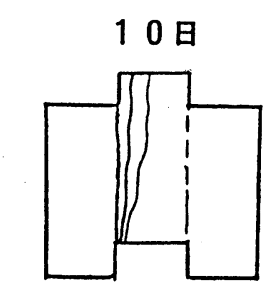

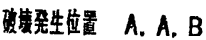

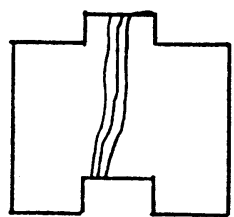

B, B, B

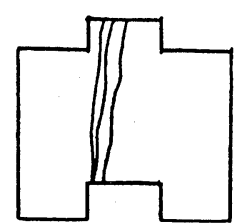

A, A, B

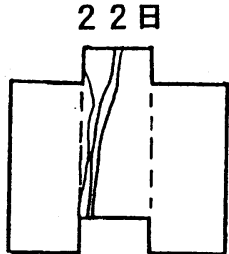

A, B, B

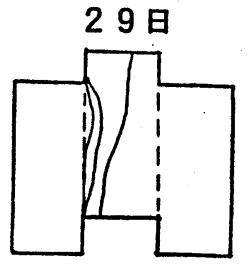

A. A. B

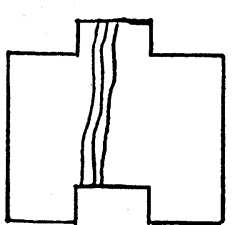

$B, B, B$

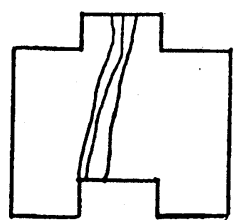

A, B, B

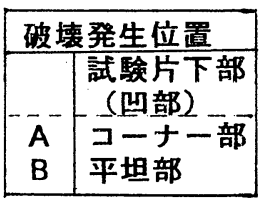

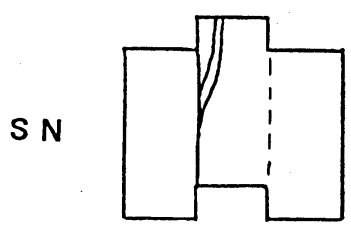

$A, A, A$

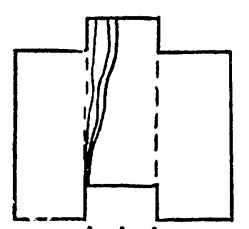

A, A, A

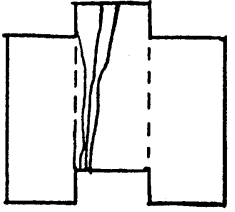

B, B, B

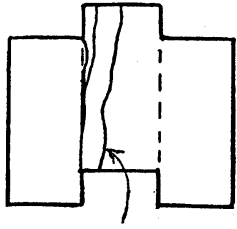

一経路一試験片
図7各試験片の代表的な破壊経路（維めたもの） A, A, B 


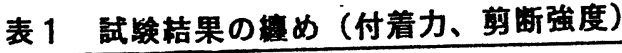

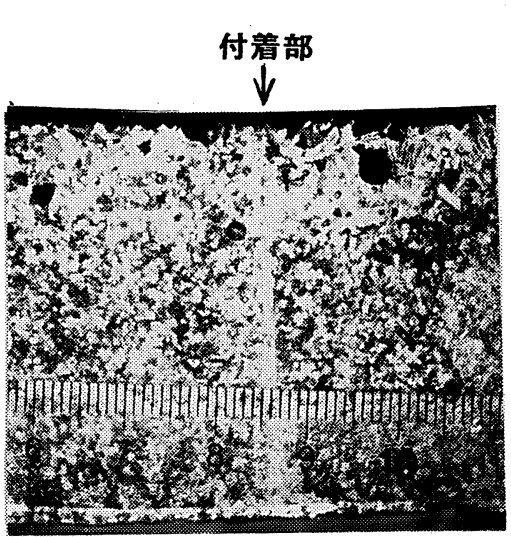

図 8 付着部の菬晶写真 ( $-20^{\circ} \mathrm{C}$ で10日間保持)

\section{F E M解析}

\section{1 解析条件}

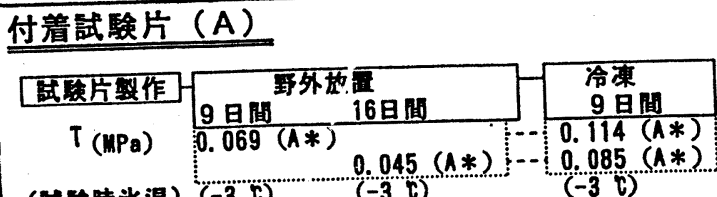

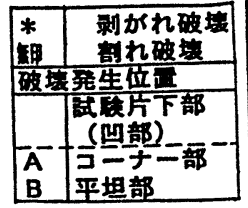

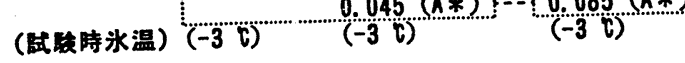

B 平坦部

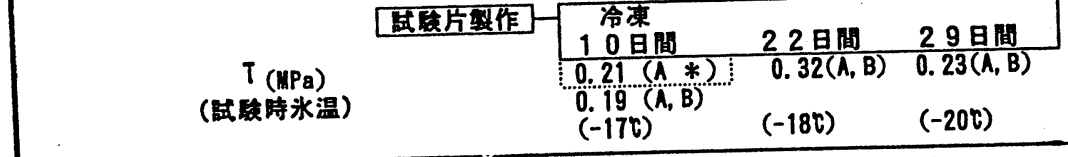

\section{剪断試験片 (S)}

\begin{tabular}{|c|c|c|c|c|c|}
\hline & 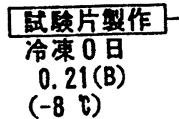 & 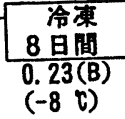 & 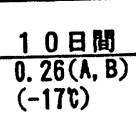 & $\frac{22 \text { 日間 }}{0.25(B)}$ & $\begin{array}{l}0.25(A, B) \\
(-20 C)\end{array}$ \\
\hline
\end{tabular}

煎断試験片 ( S N ) (切欠加工)

\begin{tabular}{|c|c|c|c|c|}
\hline 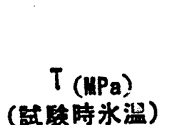 & 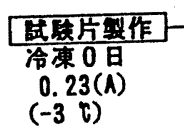 & $\begin{array}{c}\text { 冷菓 } \\
10 \text { 日闻 } \\
0.29(A) \\
(-17 \text { ( })\end{array}$ & $\frac{22 \text { 日間 }}{0.39(B)}$ & $\begin{array}{l}\frac{29 \text { 日闻 }}{0.39(A, B)} \\
(-20 \mathrm{C})\end{array}$ \\
\hline
\end{tabular}

図 9 に F E M 㗆性応力解析に用いた S N 試験片のモデル図を示す。解析には、ヤン グ率 $=300 \mathrm{MPa}$ ，ポアソン比 $=0.3$ を用いた。

\section{2 解析結果}

図10に得られた S，S N 各試験片の紊 断応力分布図（負荷応力 $=1 \mathrm{uPa}$ の場合）を 示す。この図から、F E M 解析から求めら れた付着部断面での平均畸断応力 $\tau_{\mathrm{F}}, \tau_{\mathrm{NF}}$ は、S 試験片の場合（2）式で、また、 S N 試験片の場合（3）式でそれぞれ近似 的に計算される。

$\tau_{\mathrm{F}}=0.22 \mathrm{x} \sigma_{\mathrm{o}} \quad \cdots(2)$

$\tau_{\mathrm{NF}}=1.0 \times \sigma_{0} \quad \cdots(3)$

ここで、 $\sigma_{0}$ は負荷応力 : $\mathrm{P} / \mathrm{A}_{0}$ 、

A。は負荷部面積である。

$\mathrm{S}$ 試験片の場合、(1) 式での $\tau_{\text {值は、 }}$

$\tau_{\mathrm{F}}$ 値よりも若干大きい値であること :

$\tau / \tau_{\mathrm{F}}=(\mathrm{P} /(45 \times 80 \times 2)) /(0.22 \times \mathrm{P} /(45 \times 45))=1.3$

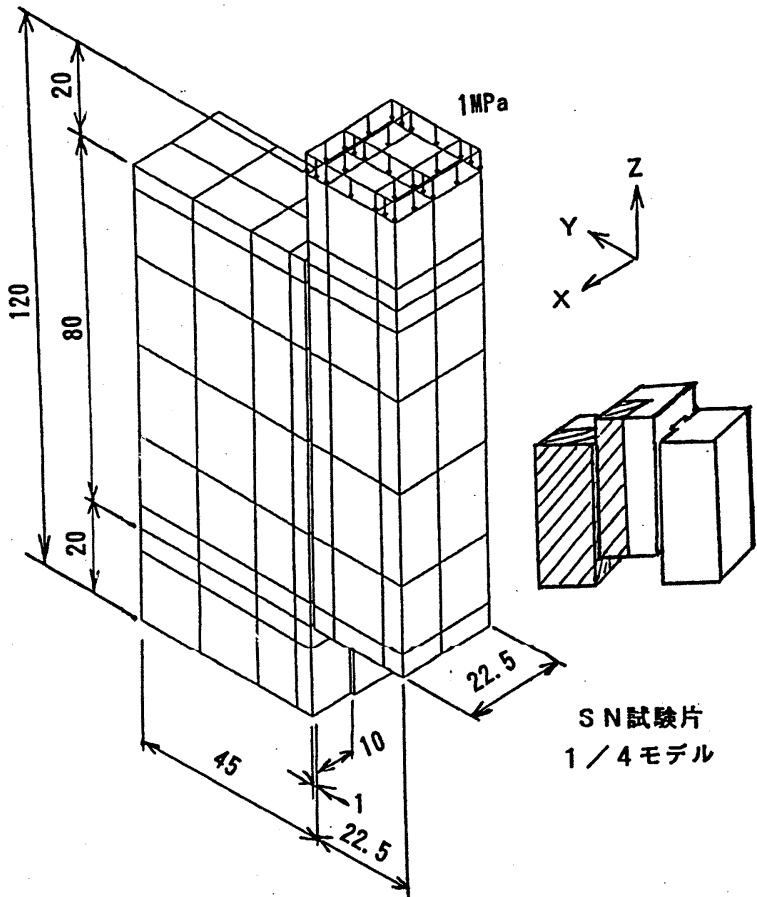

図 9 F E M弾性応力解析モデル

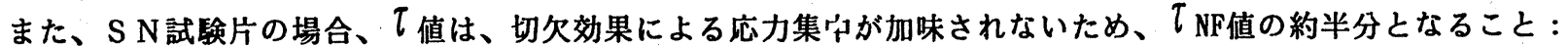

$\tau / \tau_{\mathrm{NF}}=(\mathrm{P} /(25 \times 80 \times 2)) /(1.0 \mathrm{xP} /(45 \times 45))=0.5$ がわかる。

図 11 に、F E M 解析による S、S N各試験片でのY 軸方向の応力分布をそれぞれ示す。これらの図から以下 のことが分かる。

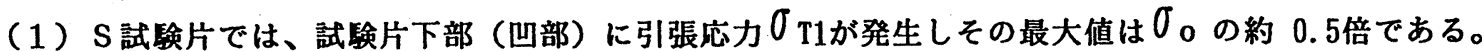

（2） S N 試験片では、試験片下部（凹部）コーナー部の切欠による応力集中が存在するため、 $\sigma_{\mathrm{T} 1} \sigma_{0}$ の 1 倍強になる。 

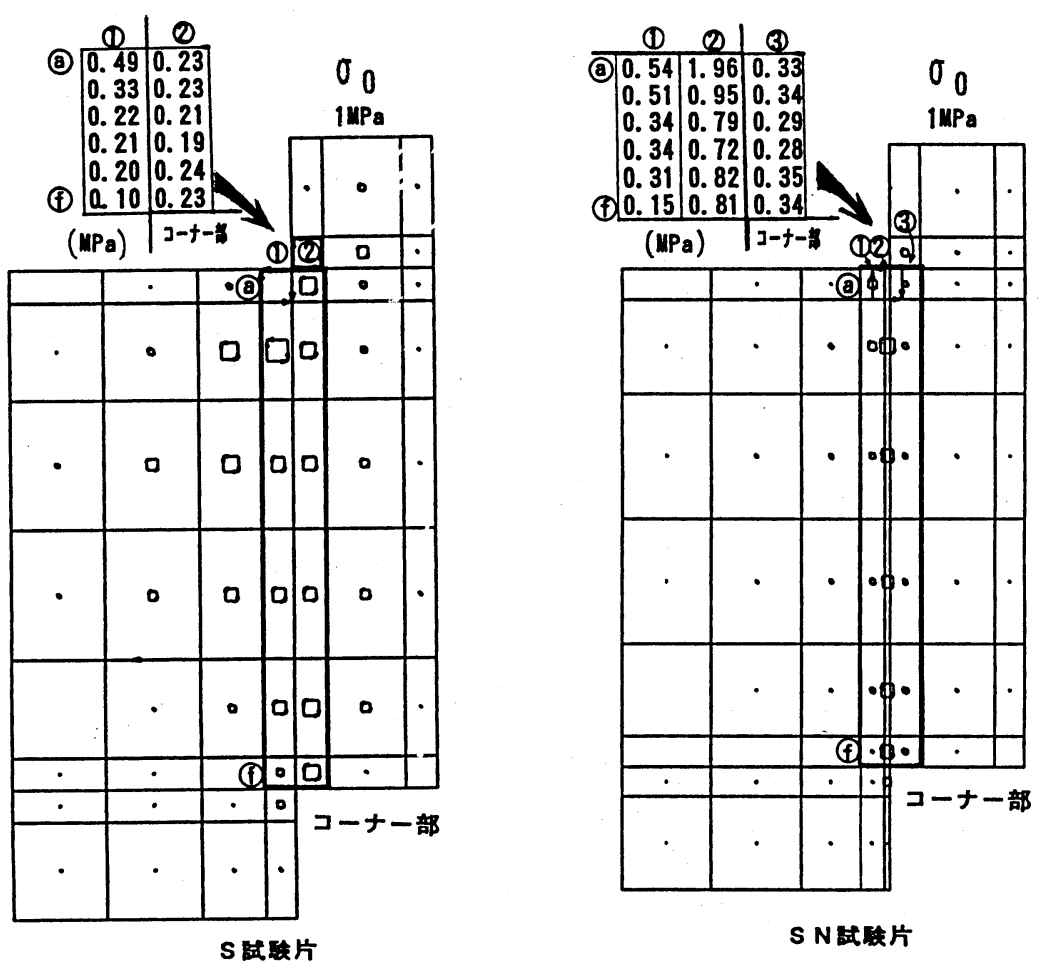

図10 F E M 弾性庆力解析轺果（剪断応力分布図)

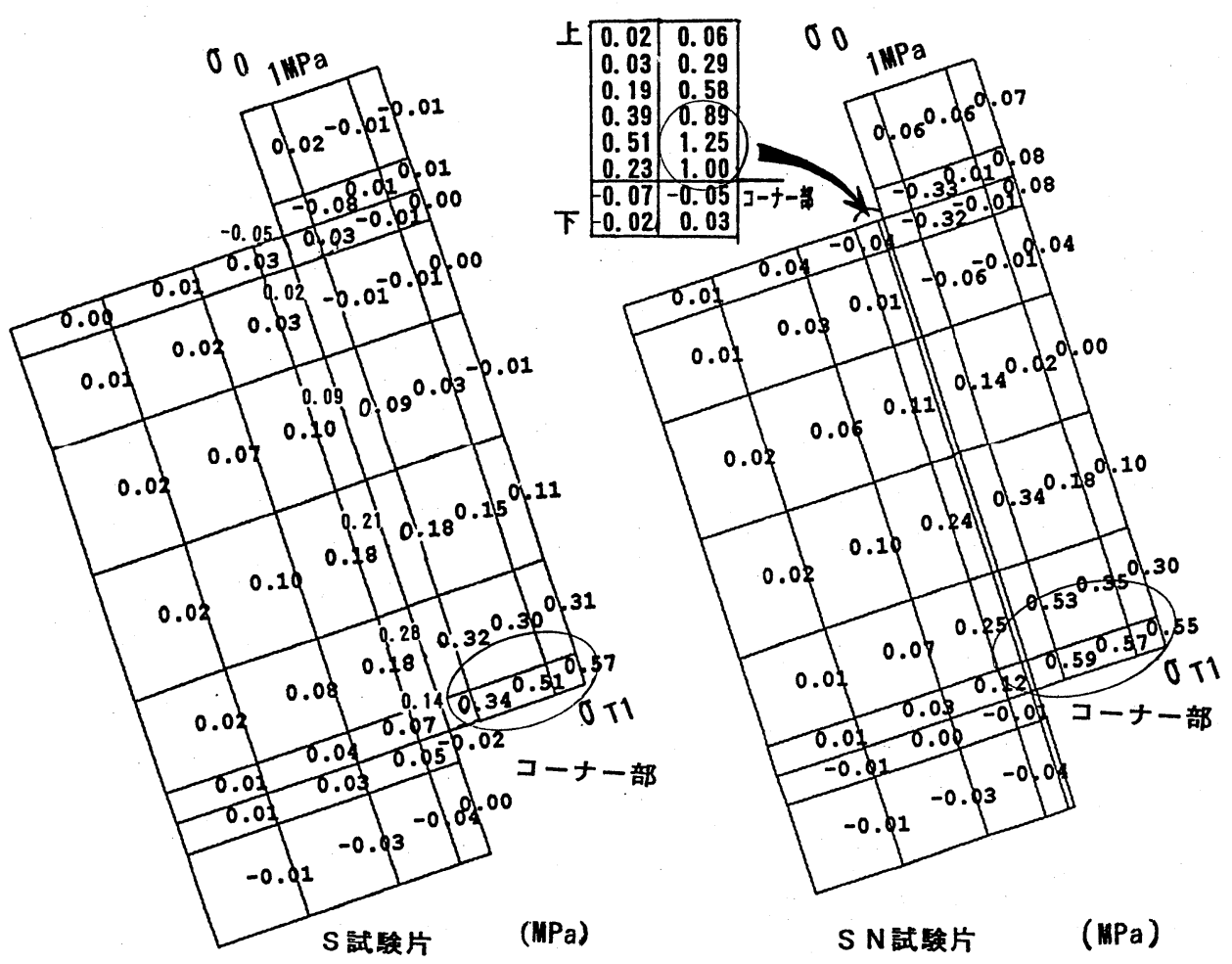

図11F E M 弾性応方解析結果 ( $\mathrm{Y}$ 軸方向応力分布図) 


\section{4. 考察}

図 12 に各試験片の破壊発生時の負荷応力 $\sigma_{\text {of }}$ と曲げ強度 $\sigma_{\mathrm{B}}$ との関保を示す。図中には、K $\sigma_{\mathrm{o}}(\mathrm{K}=0.3 \sim 1.0)$ の線図も示す。この図から、曲げ強度に対応する $\mathrm{K}$ 值は、 $\mathrm{A}, \mathrm{S}$ 試験片では0.4 0.6 の範囲に、S N 試験片で は $0.6 \sim 0.8$ の範囲になる。この結果は、 $0_{\mathrm{T}} 1$ の最大值付近の $\mathrm{K}$ 值: $\mathrm{S}$ 試験片 $(\mathrm{K}=0.34 \sim 0.57), \mathrm{S} \mathrm{N}$ 試験片 $(\mathrm{K}=$ 0.55 1.00)（図 11 参照）にほぼ対応している。また、破壊発生位置の観察結果（図 7 参照）とF E M 解析結 果 $\left(\sigma_{\mathrm{T} 1}\right.$ の最大值発生位䈯、図 11 参照) と ほぼ一致している。これらのことから、S， $\mathrm{S} \mathrm{N}$ 試験片とも試験片下部（凹部）で、 $\sigma_{\mathrm{T} 1 \text { が }}$ 曲げ強度に達した場合に破壊すると仮定するこ とが可能と思われる。

以上から、今回の試験片では、付着が強固な 場合には、曲げ強度で決まる割机破壊が試臨片 下部 (凹部) から発生することが分かる。ここ に、野外に放置した場合には、付着部の海水が 隇少しプロー等剥れの起点が存在しやすくなる ことから剥れやすくなるが、付着部に海水が多 く存在する状態で冷東した場合には海水がすぐ に冷東されるためにブロー等剥れの起点が存在 しなくなり、このことから付着が強固になり、 試的片形状で決まる応力集中部から破壊するこ とになるものと考えられる。本実験結果から、 海水や雪が海水同士の間に存在する状態で -20 ${ }^{\circ} \mathrm{C}$ に数日（10 日以内）保持されると海水同士 の付着力は急激に上昇することがわかる。

今後は、さらに 10 日以内の付着力增加の経 過過程を調べたい。

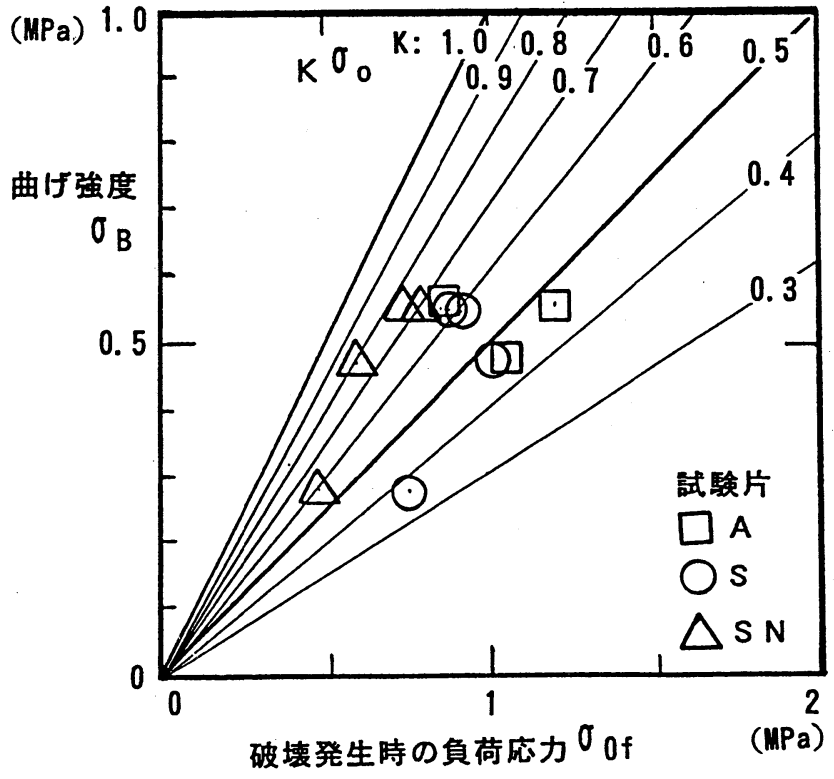

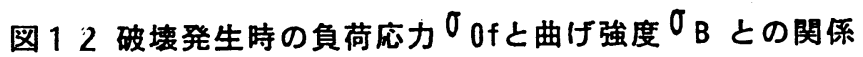

5. まとめ

一年水の海水の付着力や剪断強度を明らかにした。得られた主な結果は以下の通りである。

（1）雪と海水で接着した海水同士の付着力は、北海道の冬期（2月中）野外保管（16日間まで）の環境で、 $50 \mathrm{kPa}$ 程度、さらに-20 ${ }^{\circ} \mathrm{C}$ の冷凍庫内で 9 日保管した場合は $0.1 \mathrm{Ma}$ 程度（水温 $-3^{\circ} \mathrm{C}$ ) である。

（2）海水同士を雪と海水で接着した後-20 Cの冷凍庫内で 8 日間以上保管した場合は付着部からの剥がれ破壊 ではなく試験片形状で決まる応力集中部からの割れ破壊が支配的になる。この時の破壊条件は、“局所引 張応力が曲げ強度に達した時”と考えられる。

本研究は (社) 日本海洋開発産業協会（通称：J0IA）の「海洋構造物に及ぼす水荷重に関する研究」（委員長 佐伯浩北大教授）のもと行われたものである。本実験実施に際し島田建設（株）成田主任殿はじめ多くの方々及 び東京農業大学の学生小林君、松浦君、野中君の協力を得たので記してお礼申し上げます。

\section{参考文献}

1)松下久雄、正木孝治、竹内貴弘、酒井雅史、佐伯 浩; 海水の一軸圧縮強度について、寒地技術論文・報告集、 Vol. 12, No. 1, pp. 516-521, 1996. 11 .

2)松下久雄、高脇 透、平山健一、正木孝治、西畑昭史、花田真州、本田秀樹、佐伯 浩; 垂直壁構造物の水荷 重に関する天然水を用いた野外実験一能取湖海水の圧縮強度と曲げ強度一、寒地技術論文・報告集、Vol. 12 , No. 1, pp. 522-529, 1996. 11.

3)H. Matsushita, T. Takawaki, T. Masaki, M. Hanada, A. Nishihata, H. Saeki and K. Hirayama, “MEDIUM SCALE FIELD INDENTATION TESTS - PHYSICAL PROPERTIES AND STRENGTH OF THE ICE SHEET -” , ISOPE97, 1997.5, 投稿中 他 